\title{
Concept of Art Education: Developing Aesthetic Sensibility, Social and Situational Awareness
}

\author{
Indrayuda \\ Lecturer of Sendratasik \\ FBS Universitas Negeri Padang \\ Padang, Indonesia \\ e-mail: indrayudayusuf@yahoo.co.id
}

\begin{abstract}
This article explains the concept of art education for students in public schools. Conventionally, art education has made its mark in various institution or public school that directs towards skill-based creativity. This causes many of the students in public school unable to understand and to express the materials of art education in accordance with the objective expected by the government. This issue arises due to the teachers' poor grasp of the concept of art education. This research is done through qualitative approach by explanation method. Object of research is the concept of art learning in public schools located in West Sumatera. The observation's locations are SMA Semen Padang, SMA Negeri4 Padang, SMA Negeri4 Payakumbuh, SMA Negeri 14 Padang and SMA Negeri 1 Painan. Data is collected through observation, interview, literature study and documentation. The validation of data is done by discussion among colleagues and triangulation. Analysis is adopted from Miles and Huberman model by reducing and providing data to conclude it through verification. The research results shows that some of the teachers have poor grasp on the concept of art education and they tend to focus their teaching more on skills. This reality hindered the process of learning and teaching that results in students becoming mere audience in their art classes. It is important to expose teachers to aesthetic sensibility, as well as situational awareness and social sensibility.
\end{abstract}

Keywords - art education, aesthetic sensibility, social and situational awareness

\section{INTRODUCTION}

Art is a form of culture that has existed since the beginning of human civilization. Indirectly, humans are familiar with art since the primordial civilization, prehistory, historical times and the independence era of the world's nations to today's eraglobalization. Art is comprehended by human through collaboration of thoughts and sentiments. This results in art as not only the object to thoughts but also to contemplation of human sentiments.

Being a part of culture, art is passed down through many methods and one of these is learning. According to Manan (1999:79), as art is a part of culture, it possesses unique characteristics that are different from other elements of culture. Therefore, art and the other elements of culture must be passed down through teaching and learning. In Indonesia, art and other elements of culture are passed down traditionally by learning process. Either children and parents, grandchildren and grandparents or uncles and aunts, everyone went through the learning process. Besides that, it is also passed down traditionally from teachers to students and the process takes place in 'schools' in Minangkabau and Jawa which in both native language is known as sasaran and padepokan respectively.

Learning, especially art learning, has come a long way since the yesteryear in terms of purpose, objective, strategy and concept among the community before and the community today. The teacher-student structure has been around for quite some time in padepokan or sasaran and they practice oral-based curriculum as well in the past. Conceptually, it is different with the learning system today that is based on schooling.

Brandon (1967) and Winangun (2015) mentioned that art learning traditionally was developed by villages' community in Indonesia through transformation from teachers to students. The teachers applied traditional approaches such as mannerism and traditional ethics that are practiced among the local community and same goes with methods and learning governance.

Traditional art education oriented on local values is governed by local approach. It shows that through the approaches mentioned, traditional art can withstand the test of time despite being passed down from centuries ago. Traditional art education is able to sustain due to the concept of persuasive learning. Adding to that, humanity, religious and kinship approach turned art into cultural identity maintained by community among villages. Art education in the past is not based on schooling which applies distinctive curriculum and teaching structure and also structured evaluation as it is now in SD, SMP and SMA in Indonesia. Nevertheless, traditional art education produces art's sustainability and became a cultural heritage in today's Indonesia.

Art education functions and aims to build tolerance, democracy, civilization and harmonious living among the diverse community. Other than that, it is also intended to widen students' intellectual imaginative skill and expression through art. To ensure these, it is important to develop aesthetic sensibility and competency, as well as applying technology in creative process and in presentation and performance of artwork.

In addition, art education has great impact towards mental and physical development of the learners. Through art education, learners are trained to develop good manners and behaviours because art introduces norms and values of its community 
and practitioner to the learners. In that sense, teachers' behaviour play a big role in teaching process and same goes to the material given to students as recipients of knowledge (Suhaya, 2016:3).

Yandwi (2016) found that many art teachers such as dance teachers in West Sumatera are still unable to grasp the concept of art education. These teachers liken their understanding of cultural art education in school to dance classes outside. It is to an extent where a school principal assigned an English subject teacher who can dance to teach the art of dance to students in seventh grade. In term of competency, the teacher has skills but theoretically does not understand the nature of true art education. This leads to ineffective learning in educational aspect.

Cases found in SMA Negeri 4 Padang, SMA Negeri 4 Payakumbuh, SMA Negeri 14 Padang and SMA Negeri 1 Painan show that there exist studio and profession-oriented art education. This proves that the teachers prioritize learning based on skill and demand students to be skilful in dancing and singing, and the outcome produces expert and competent students. Unfortunately, the result of this type of education produces unresponsive students towards the art learning.

In reality, there has been miscommunication between students and teachers in the process of art education, especially cultural art. It is not uncommon that students break rules and became uninterested in learning and even debate with teachers in the process. The learning standard set by the teachers come as a burden for students that they appear to be less responsive towards the material presented in classes.

Schooling-based art education is expected to be better and enables art to be passed down to students as the successor of the new generation as well as practiced in the traditional art education in padepokan in Jawa or sasaran in Minangkabau. In turn, the art can survive and develop among the community of its supporters. Schools, as the gateway to new generation, must be the agent responsible for the sustainability of art. One of the methods is through true art education in terms of teaching, values, learning and application.

It is assumed that there has been confusion in the concept of art education in Indonesia, especially West Sumatera. Some teachers misunderstood that art education aims to produce skilful students. The method they applied in teaching students is of carrying evaluation for the students' skills as if they are evaluating professionals. Unfortunately, the expectation for art education (cultural arts) curriculum has not been met. Therefore, this article will further discuss the issue in art education concept and offers ideas on the concept of art education applied in public schools in West Sumatera.

\section{METHOD}

This research is done in four schools in West Sumatera, namely SMA Negeri 4 Padang, SMA Negeri 4 Payakumbuh, SMA Negeri 14 Padang and SMA Negeri 1 Painan. It is a qualitative descriptive research that represents research setting condition as it is. Data collection is done through observation of teachers' and students' behaviour, activities of teaching and learning processes in classroom and situation and condition outside of the classroom.

Interviews are done to gather information from students and teachers regarding the process of teaching and learning as well as the learning results. Other than that, interviews are also done to gather students' respond towards the material and evaluation of learning and also interaction between teachers and students. Data documentation from the archives, activity reports, study results are collected by researcher as research data. Researcher, as the key instrument, plans the research by making research grid and perform data collecting with the aid of audio visual media.

Analysis are done through the stages of collecting data by interviews, observation and documentation of teachers' and students' activity data, collecting the data content of education concept in use and the results of teaching and learning process done by the teachers. All of the data are selected to be analyzed by evaluating the problems and guided by the research questions and supporting theory. Researcher then verified the valid data and interpret it.

The validation of data is done through discussion among colleagues and triangulation. Validation of data takes place by placing data in different situations and repeated to adapt to the question asked.

\section{FINDING AND DISCUSSION}

Teachers today tend to apply studio-oriented teaching in their teaching process. They often induce opinion and view such as learning about art is to be an individual who is skilful in the art field.

Yesti Marni, a cultural art teacher in Padang, admits that teaching art as much as possible results in students becoming competent in creating art. Students gain recognition and became winners in competitions and festivals and further require them to learn to dance and sing with excellent skills. It turns out that the objective and purpose of teachers are to train their students to become experts and competent in performing and creating arts.

There are also teachers that are found to focus their classes only on skills. They implore that students who are skilled in singing, dancing or playing musical instruments and acting are those who will be deemed as having certain quality in art education. In reality, not all students take that view seriously. Many are unprepared in term of skill to accept that type of art education concept.

The fundamental issue lies on teachers having stereotypical view that art is a skill. This paradigm has deeply rooted among art teachers (cultural art) in West Sumatera that they demand students to be skilful post learning process. 
Theoretically, teachers understand the meaning of art education. They are even aware that the purpose of art education in education field is to carry on the values incorporated in local and national culture, from one generation to another. Education in formal school are not limited only to development of intellectual, but also observation on the emotional development of every students. Basically, art education is an education that nurtures the aesthetic sense to help shape the people of Indonesia in becoming strong and balanced, aligned with personal development by observing social surroundings, culture, nature and its connection with God (Depdiknas, 2003: 3-4).

The emphasis is on the aspect of aesthetic sense development along with surroundings and environmental development. Art education in public schools is directed to produce individuals that behave aesthetically and are aware of the social and environmental surroundings as the source of life. By doing this, it will not be a purpose for education in public schools to only produce skilful students in creating art until it becomes a profession for the students.

In schools such as SMA Negeri 4 Padang, SMA Negeri 4 Payakumbuh, SMA Negeri 14 Padang, and SMA Negeri 1 Painan, the concept of art education for them is to build creative and skilful students' behaviour as artists. This further proved that the said concept is adapted in reality that the requirements to learn to be an expert and being skilful are more dominant compared to the requirement to develop aesthetic sensibility and social awareness. Truthfully, the more important matter to be done is to develop aesthetic sensibility and situational awareness as well as environment by creating arts.

Art education in public schools is a vocational, which means that art is an educational media. Further explanation says that art is an educational tool to educate students to become human being with thoughts and sentiments, and are able to develop their behaviour as useful human being. Art will be used to educate students to be creative, innovative and sensible towards surroundings, be it residence, school and environment. Art will then act as tools to think logically and systematically because logic is needed in evaluating art such as in music, where there has to be accuracy in pitch and tempo, and in dance, style, frequency, space, energy and time.

Focusing on the structure of aesthetic experience, diversity is as important as unity. Unity will function only by the control of various element. The concept of unity in diversity as regularity presents a norm in art that is incidentally realized in many artwork. Unity in diversity may exist in one out of three form, which are harmony or unity of teamwork element, development or evolution of a process heading towards the end or the climax (Titus in Afendi, 2016:5).

Referring to the structure of aesthetic element, researcher can express that the concept of art education as avocational in public schools cannot be separated from aesthetic sensibility. Structurally, aesthetic experience can shape harmonious behaviour among students. Therefore, the implementation of art education must be rooted to art as educational media in developing harmonious awareness in interaction between students and teachers as well as among students. This can be seen in the harmonious unity of movement and music, voices and instruments. This type of sense must be emphasized by the teachers as art educator in schools.

According to Suhaya (2016:4), art education is the thought of building "perception" on art and beauty, implemented through observation, be it presenting or observing, by visiting art objects in museums, artist's studio, exhibition and many more.

Art education must be directed to shape students' sensibility and the awareness of the surroundings' beauty, and that it is a gift from God. It is a space to socialize, to interact and to integrate. In turn, the awareness must be developed along with art through education in public schools.

Therefore, students must place art as a tool to view the surroundings, be it environment or social. For example, the peacock's dance is a reflection of its surroundings and a representation of its behaviour living in a free world. The meaning behind this dance has become a debateable matter in art education that causes students to be directed towards situational awareness education. This teaches students that there are other living beings that occupy this world.

According to Manan (1999:79), art, as a part of culture, possesses unique characteristics compared to other elements of culture. Art and other cultural elements must be passed down by learning and teaching. Because of its uniqueness, art must be pursued with accurate concept. This is the reason why art education orientation leans towards development of value, characteristics of students' awareness for the aesthetic and situational and social awareness as tools to shape students' personality as social beings.

The researcher sees that art education concept based on skills and expertise that is taking place in West Sumatera ought to be transformed to the concept of aesthetic sensibility, situational and surroundings awareness. By doing this, art education implemented in public schools can be aligned with the purpose of national education, which is to develop aesthetical behaviour to help build the people of Indonesia to become stronger and more balanced. It will prosper personal development by observing the social, cultural, environmental surroundings and its relationship with the Almighty.

\section{CONCLUSION AND RECOMMENDATION}

Art education in public schools must be appointed towards avocation rather than vocation. This is because public schools does not demand students to be skilful and expert in art, rather it aimed to implement sense in terms of aesthetic and situational awareness in order to live harmoniously.

Therefore, the concept of art education in public schools is to train students to be sensible towards aesthetic, social values, surroundings and environment. Eventually, art education will develop students' integral, harmonious, innovative and 
creative behaviour. Through these, students will learn that art is comprised of discipline, harmony, systematic and toleration, as well as interaction that are integrated to each other.

\section{References}

Afendi, Zul. (2016). Watak Nilai Nilai dan Pengalaman Estetika: Pilihan Nilai-Nilai. Makalah Tidak Dipublikasikan disampaikan dalam Seminar Pascasarjana Universitas Negeri Padang Tanggal 23 Oktober 2016. Padang: PPs. UN P.

Brandon, James R. (1967). Theatre in Southeast Asia. Cabridge, Massachusetts: Havard University Press, 1967.

Depdiknas, (2003). Petunjuk KurikulumPendidikan Kesenian Berbasis Kompetensi. Jakrta: Depdiknas.

Imron, Ali. (2008). KebijakanPendidikan di Indonesia. Jakarta: BumiAksara.

Kadir, Sardjan. \&Ma'sum, Umar. 1982. Pendidikan di Negara sedangBerkembang. Surabaya: Usaha Nasional.

Manan, Imran. (1999). Antropologi Pendidikan. Padang: PPs UNP.

Suhaya. (2016). Pendidikan Seni Sebagai Penunjang Kreatifitas. Jurnal Pendidikan dan Kajian Seni, Vol.1, No.1, April 2016: 1-15ISSN 2503-4626.

Winagun, Agnes Wiranti. (2015). Problematika Pembelajaran Seni Budaya di SMP 2 Rengat: Studi Kasus Kebijakan Kepala Sekolah Terhadap Mata Pelajaran Seni Budaya. Tesis Pada Program Pascasarjana UNP. Padang: FBS UNP.

Yandwi, Pragia Vesca. (2016). Ketimpangan Kualifikasi Guru dengan Pelaksanaan Pembelajaran Seni Budaya di SMP Negeri 5 Solok. Hasil Penelitian Tidak Diterbitkan. Padang: FBS UNP. 